\title{
What Difference Do Mayors Make? The Role of Municipal Authorities in Turkey and Lebanon's Response to Syrian Refugees
}

Alexander Betts, Fulya Memisoglu, and Ali Ali

\begin{abstract}
With the majority of refugees now in urban areas, mayors and municipal authorities have been recognised as increasingly important policy actors in the global refugee regime. This trend is acknowledged in the policy literature. However, there has been little systematic academic research exploring the conditions under which mayors make a difference to refugee policy outcomes. Theoretically, we outline a heuristic framework aimed at disaggregating key variables, including the independent influence of mayors, in shaping municipal level outcomes. Empirically, the article assesses the role of municipal authorities and mayors in the two most numerically significant host countries for Syrian refugees: Turkey and Lebanon. It comparatively examines variation across six metropolitan municipalities, three from each country: Izmir, Adana, and Gaziantep (Turkey), and Qalamoun, Anjar, and Zahle (Lebanon). We show that mayors matter because they may mediate the implementation of national policies and because they sometimes adopt supplementary refugee policies and practices at the municipal level.
\end{abstract}

\section{Introduction}

The Syrian refugee crisis has been the largest mass displacement of the Twenty-First Century. Over 12 million people have been displaced, 6 million internally displaced within Syria, over 5 million in the neighbouring countries in the Middle East (Turkey $3.5 \mathrm{~m}$, Lebanon $1 \mathrm{~m}$, and Jordan 660,000), and 1 million in Europe (over half of whom went to Germany). Across the main host states, there has been significant variation in responses, across indicators such as admission to territory and the right to work. As is widely acknowledged in the comparative politics and international relations literature on refugees, many of these variations can be explained by politics (Hamlin 2014; Mylonas 2013; Lischer 2005; Milner 2010; Salehyan 2009). Indeed, sources of variation in national policies towards Syrians have been explored for Europe (Fargues and Fandrich 2012; Kallius et al 2016; Ostrand 2015); and the Middle East (Chatty 2017; Turner 2015; Dionigi 2017; Miller 2016; Tsouparas 2017; Içduygu 2015). Most of this literature examines the politics of the Syrian refugee crisis at the national and international level.

Refugee politics, however, is not exclusively determined by what happens at the nation-state level. Looking at politics in Amman, Beirut, or Ankara will only tell you so much about the politics of host states. Although increasingly urban, refugee-hosting in low and middleincome countries often takes place in geographically remote areas, close to international borders. Consequently, it frequently implicates a range of sub-national actors and structures. 
Refugee politics is often 'local' politics; regional, district, and municipal authorities are often key gatekeepers (Landau and Amit 2014). Whether they perceive refugees as an opportunity or a threat shapes not only local policies but also the creation and implementation of national (and international) policies. Irrespective of national legislation and policy statements, the practice of everything from refugee-status determination to the right to work is influenced by sub-national politics. Evidence for this stems from a simple observation: even where there is a common national policy framework, there is frequently sub-national variation in practice and implementation (Milner 2010; Schmidt 2014; Orchard 2014).

Moving beyond methodological nationalism, municipal authorities and mayors have been identified in the policy literature as important in shaping outcomes for Syrian refugees, sometimes adopting more 'progressive' and at other times more 'restrictive' policies compared to the national level. In Altena in northwest Germany, Mayor Andreas Hollstein was famously stabbed in protests against his inclusive policies towards Syrians. In Lebanon, the mayor of Zahle, As'ad Zughayb, has overtly chosen not to implement the more draconian policies of the central government. In Turkey, the mayor of Gaziantep, Fatma Şahin, has directly engaged international actors such as the European Union in support of municipal level policies. Reflecting this trend, a Global Mayors Summit on Refugees and Migrants, was hosted by New York mayor Bill de Blasio on 18-19 September 2017 alongside the UN General Assembly. In contrast, in France, the mayors in a number of French towns have systematically highlighted the problems created by hosting refugees.

The growing importance of cities as a level of governance, and mayors and municipal authorities as key actors, is widely acknowledged in literature in geography and political sociology (Brenner 1998; Sassen 2002). Cities have been identified as a key site of a wider trend of 'glocalization', challenging state-centrism and methodological nationalism (Robertson 1995; Roudometof 2005). Meanwhile, mayors have increasingly been recognised as important global actors, engaging with issues conventionally understood as 'international' (Barber 2013; Ljungkvist 2015). Globalisation has contributed to urbanisation and connected cities directly to major global challenges, such as climate change, immigration, and transnational organised crime. The role of cities and mayors has, for instance, been explored in relation to issue areas such as climate change (Bansard et al 2017) and the Sustainable Development Goals (McGranahan 2016). 
Yet the role of mayors in relation to refugees has yet to be explored systematically from a social scientific perspective. In this article, we aim to address that gap by assessing whether and how mayors have mattered in the politics of the Syrian refugee crisis. In doing so, we seek to contribute to both the literature on refugee politics and to the wider political science and international relations literature on the role of cities as actors in world politics (Acuto 2010, 2013; Curtis 2014, 2016; Ljungkvist 2015; Amen et al 2011; Kangas 2017).

One largely unaddressed challenge in the wider literature on mayors in world politics has been how to attribute causal influence. For example, how can we distinguish the influence of the municipal level of governance from the role of the mayor qua actor? If we observe deviation in municipal level policy from the national level (positive or negative), to what extent is this structurally determined by municipal level polities, on the one hand, or the agency of a particular mayor, on the other hand? Reflecting these challenges, we are broadly interested in three sub-questions. First, do municipal policies towards Syrian refugees diverge from national level policies? Second, if they do, to what extent are divergences attributable to particular mayors? Third, what explains the sources of divergences and the relative influence of particular municipalities and mayors?

Methodologically, we focus on the role of municipal authorities and mayors in the two most numerically significant host countries for Syrian refugees: Turkey and Lebanon. We examine variation across six metropolitan municipalities, three from each country: Izmir, Adana, and Gaziantep (Turkey), and Qalamoun, Anjar, and Zahle (Lebanon). We select the municipalities on two grounds. First, each one hosts Syrian refugees. Second, each one has a different political identity and hence relationship to the central government. In Turkey, for instance, all three cities have different governing political parties at the metropolitan municipal level (CHP in Izmir, MHP in Adana, and AKP in Gaziantep). In Lebanon, all three cities have different confessional or identity structures, which is reflected in the coalitions of political parties that dominate (Sunni in Qalamoun, Armenian in Anjar, and Christian in Zahle). For each municipality, we undertook primary fieldwork based on semi-structured elite interviews, including with representatives of the municipal authorities and other relevant actors between September 2016 and May 2017. In this article, we use a combination of process tracing and counter-factual analysis to assess the extent to which policy outcomes would be different in the absence of, first, the municipal level of governance and, second, the incumbent mayor. 
The article is structured as follows. First, we outline a conceptual framework for understanding the role of municipal authorities and mayors in refugee politics. Its purpose is to both to offer a preliminary framework for disaggregating the political influence of mayors on policy outcomes, and to clarify of our main dependent and independent variables of interests. Second, reflecting the primarily empirical contribution of the article, we assess the role of the municipal authorities and majors within each of our six cases. For each case, we a) examine the extent to which refugee policy is more or less proactive and more or less restrictive compared to the national level; b) assess the extent to which this divergence is attributable to the particular incumbent mayor; c) evaluate the main sources of influence that led to deviation. Finally, we conclude by comparatively assessing the factors underlying municipal level-central government divergence on refugee policy across the six cases, and what implications this has for the literatures on refugee politics and the role of mayors in world politics.

\section{Theoretical Framework}

Most of the political science and international relations literature on refugee politics takes the state as its primary level of analysis, either explaining intergovernmental interaction (Loescher 2001; Suhrke 1998; Haddad 2008; Orchard 2015; Greenhill 2010) or variation and change in national policies (Thielemann 2003; Lischer 2005; Hamlin 2014). Only rarely is the state disaggregated. And yet, a particular, and well-noted feature of refugee politics is that it is subject to multi-level governance. Legal and institutional structures exist at the global and regional levels, which are adopted and incorporated at the national level, and then implemented within particular local contexts. Only rarely, though, has the interaction between levels of governance, and especially and analysis of local level politics been incorporated into work on refugee politics (Schmidt 2014; Orchard 2014; Milner 2009).

Furthermore, one particular set of 'local' actors has been almost entirely neglected: municipal authorities and mayors. And yet today, in the context of growing urbanisation, more than half of the world's refugees live in cities. In low and middle-income countries, where over $85 \%$ of the world's refugees are based (UNHCR 2017).

Political science and international relations has long developed conceptual tools useful for examining multi-level governance (Hooghe and Marks 2001; Bache and Flinders 2004), and for exploring the interactions between international, national, and local politics (Gourevitch 1978; Moravcsik 1995; Katzenstein 1976; Finnemore and Sikkink 1998; Acharya 2004; 
Cloward 2015). In contrast, though, it has, until recently, largely neglected the role of the city within this type of multi-level analysis. Ljungkvist (2015) has suggested that, in theoretical terms, cites have been the 'missing elephant' in international relations theory. She further suggests that they are important insofar as they can exert autonomous influence on political outcomes. But, she acknowledges, work remains to be done to explain the conditions under which this autonomous influence arises. Indeed, despite a growing body of work highlighting how cities engage with transnational issues (Acuto 2010, 2013; Curtis 2014, 2016), few conceptual models exist to explain when and under what conditions municipal authorities and mayors matter for shaping outcomes in particular global policy fields, such as refugees.

The conceptual gap exists partly because theorising the political role of the city in relation to global policy fields entails a range of conceptual challenges (Kangas 2017). Should the city be understood as a national or a transnational actor? Should it be understood as a level of governance or as an actor? Does it need to be further disaggregated, for instance to distinguish municipal authorities from mayors? Inevitably, the salience of particular actors and levels of governance will vary across global policy fields. In responding to particular transnational challenges, the relevance of cities will not be uniform. Consequently, our aim is not to offer a general theory of how municipal authorities and mayors shape policy outcomes. Rather, it is to offer a simplified framework that can help us to explain their role in the refugee context.

In this article, our theoretical goal is relatively modest. Since the article is based on a qualitative study of six contexts, we do not aspire to develop a generally applicable theory nor to undertake theory-testing. Instead, we draw upon the findings from our cases to outline a simplified heuristic framework that can contribute to theory-building which might then guide subsequent comparative analysis, and be later tested more widely. Our framework is designed to be able to meaningfully respond to our three sub-questions: Do municipal policies towards Syrian refugees diverge from national level policies. If they do, to what extent are divergences attributable to particular mayors? What explains the sources of divergences and the relative influence of particular municipalities and mayors?

Reflecting this, the main dependent variable is municipal level refugee policy. We are interested not just in describing those policies but in assessing the degree to which they diverge from national level policy. In particular, there are two forms of deviation we are interested in, relating to the two underlying aspects of most low and middle-income country 
refugee policies: development and security. On the 'development' side, to what extent are they more or less proactive in providing additional supplementary public services in areas like education and employment? On the 'security' side, are they more or less restrictive towards refugees than central government policy suggests? In other words, to what extent do they enforce central government security measures on issues like counting, curfews, and crackdowns?

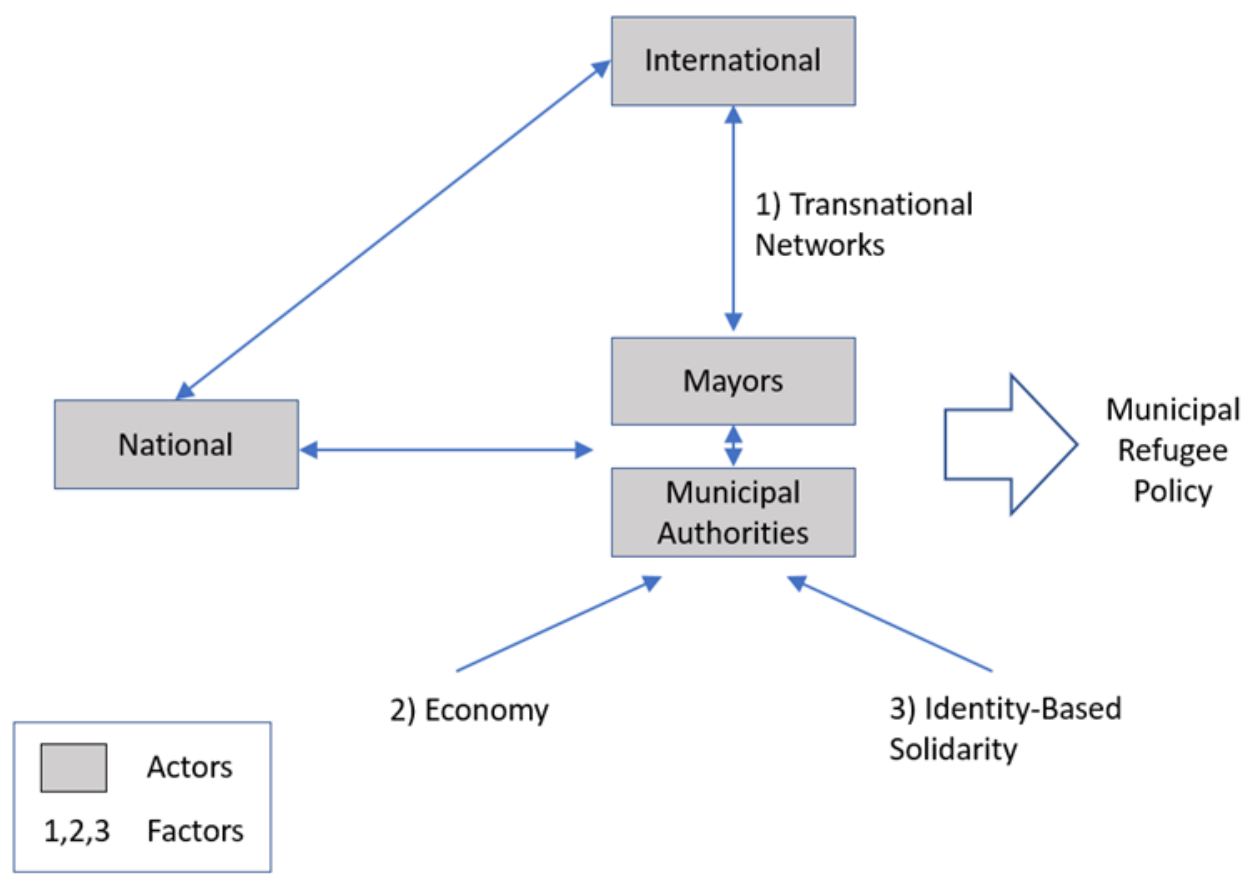

Figure 1: Conceptual Framework: How Mayors Matter for Refugee Policy

In order to explain this variation, we outline our heuristic framework in Figure 1. Its aim is to isolate the factors that explain variation in municipal refugee policy. When are policies more or less proactive or restrictive than the national level? The framework identifies the key actors and factors that shape municipal refugee policy. As Chatty (2017) observes, in different Syrian refugee-hosting countries, the national and municipal levels have exerted different degrees of influence on refugee policies. In Turkey, she suggests the national level is relatively more important, compared to Lebanon, for which the municipal level is relatively more important.

At the city-level, we distinguish between 'municipal authorities' and 'mayors'. For municipal authorities, two sets of factors shape variation in policy outcomes. First, the economy: is the presence of refugees perceived as a cost or benefit for the municipal economy? Second, 
identity-based solidarity: how much solidarity exists between dominant identity groups within the municipality and the refugee community? In different countries, the particular manifestation of identity that matters for policy outcomes differs. For example, in Turkey, political parties (e.g. AKP, MHP, CHP) are the most important source of variation, whereas in Lebanon, it is confessionalism (e.g. Sunni, Shia, Christian). To a large extent, these factors mirror the national-level political science literature's debate on the relative influence of economic and cultural variables in shaping the relative inclusiveness of refugee policies (Dinas et al. 2019; Hainmuller and Hangartner 2016; Bansak et al 2016; Hangartner et al 2019).

However, there is not a structurally deterministic relationship between economic and cultural context, on the one hand, and municipal-level refugee policies, on the other hand. Individual mayors can make a difference, whether in reinforcing or overriding local structural influences. While this may well be influenced by the individual's personality and values, a key factor in shaping the relative influence of individual mayors appears to be their transnational networks. The most tolerant mayors in our study, Fatma Sahin and As'ad Zoghaib, have in common that they cultivated direct connection to international actors, bypassing the national government. They built relationships with United Nations actors, received access to funding lines usually channelled through central governments, and have been exposed to global cosmopolitan narratives.

Empirically operationalising this framework across the six case studies involves using process tracing (Bennett and George 1997) to infer the extent to which particular municipallevel factors versus the role of individual mayors has mattered. Isolating particular variables based on a limited number of qualitative cases presents a need to use counterfactual analysis to ascertain the particular influence of mayors. A particular challenge within our cases studies has been that mayors' policy influence has tended to reinforce rather than contradict the underlying structural trends relating to economic context and identity-based solidarity at the municipal level. In terms of theory-testing, it would be desirable to base case selection on a larger number of cases in which mayors' influence overcame restrictive or proactive tendencies at the municipal authority level. In our case countries it is unsurprising that there are few cases that meet this standard given the ways in which mayors are generally selected: in Turkey this is generally from party lists; in Lebanon it is generally either by municipal authority appointment or election from party or interest group lists. Nevertheless, through counterfactual analysis (Tetlock and Belkin 1996; Bennett 1987; Lebow 2000), we are able to 
identify contexts in which particular forms of restrictive or proactive policy would not have taken place in the absence of that particular mayor. The application of the theoretical framework to the empirical cases is summarised in the Tables 1 and 2 below.

\begin{tabular}{|c|c|c|c|}
\hline \multirow[t]{2}{*}{ Municipality } & \multirow[t]{2}{*}{ Refugee Policy } & \multicolumn{2}{|l|}{ Explanation } \\
\hline & & Municipal Authority & Mayor \\
\hline Gaziantep & $\begin{array}{l}\text { Active solidarity } \\
\text { (additional socio- } \\
\text { economic support } \\
\text { provided) }\end{array}$ & $\begin{array}{l}\text {-AKP (Muslim } \\
\text { fraternity and } \\
\text { hospitality: most pro- } \\
\text { refugee party) } \\
\text {-No additional } \\
\text { resources from central } \\
\text { government } \\
\text {-Strong economy; } \\
\text { refugees' economic } \\
\text { contribution } \\
\text { encouraged }\end{array}$ & $\begin{array}{l}\text { Fatma Şahin (2014- } \\
\text { present) } \\
\text {-Seek international } \\
\text { assistance } \\
\text {-Migration affairs unit } \\
\text {-Special schools and } \\
\text { community centre }\end{array}$ \\
\hline Adana & $\begin{array}{l}\text { Selective solidarity } \\
\text { (support for ethnic } \\
\text { Turkmen refugees) } \\
\text { (variation across } \\
\text { District } \\
\text { Municipalities) }\end{array}$ & $\begin{array}{l}\text {-MHP (nationalist- } \\
\text { right: identity-based } \\
\text { refugee policies) } \\
\text { - No additional } \\
\text { resources from central } \\
\text { government } \\
\text { - Strong economy; } \\
\text { refugees' economic } \\
\text { contribution not 'too } \\
\text { significant or visible' }\end{array}$ & $\begin{array}{l}\text { Hüseyin Sözlü (2014- } \\
\text { present) } \\
\text { - Disengaged mayor } \\
\text { - Delivery of emergency } \\
\text { assistance (also } \\
\text { transnational aid for } \\
\text { Turkmens) }\end{array}$ \\
\hline Izmir & $\begin{array}{l}\text { Disengaged } \\
\text { (variation across } \\
\text { District } \\
\text { Municipalities) }\end{array}$ & $\begin{array}{l}\text {-CHP (centre-left: } \\
\text { portrays refugees as } \\
\text { burden) } \\
\text {-No additional } \\
\text { resources from central } \\
\text { government }\end{array}$ & $\begin{array}{l}\text { Aziz Kocaoğlu (2004- } \\
\text { present) } \\
\text { - Disengaged mayor } \\
\text { - Minimal assistance }\end{array}$ \\
\hline
\end{tabular}




\begin{tabular}{|l|l|l|l|}
\hline & $\begin{array}{l}\text { - Strong economy; } \\
\text { refugees' economic } \\
\text { contribution unknown }\end{array}$ & \\
\hline
\end{tabular}

Table 1: Summary of empirical findings relating to municipalities in Turkey.

\begin{tabular}{|c|c|c|c|}
\hline \multirow[t]{2}{*}{ Municipality } & \multirow[t]{2}{*}{ Refugee Policy } & \multicolumn{2}{|l|}{ Explanation } \\
\hline & & Municipal Authority & Mayor \\
\hline Zahle & $\begin{array}{l}\text { Tolerant } \\
\text { (not implement } \\
\text { October Policy, } \\
\text { and seek } \\
\text { additional } \\
\text { support) }\end{array}$ & $\begin{array}{l}\text {-Mainly Christian } \\
\text {-Mayor elected from } \\
\text { "Zahle Development } \\
\text { List" }\end{array}$ & $\begin{array}{l}\text { As'ad Zoghaib (2016-) } \\
\text {-Direct relationships with } \\
\text { international } \\
\text { organisations } \\
\text {-Choice not to implement } \\
\text { curfews } \\
\text {-Active data collection }\end{array}$ \\
\hline Anjar & $\begin{array}{l}\text { Selective } \\
\text { solidarity } \\
\text { (support for } \\
\text { ethnic Armenian } \\
\text { Syrians) }\end{array}$ & $\begin{array}{l}\text {-Mainly Armenian - } \\
\text { Tashnag party } \\
\text {-Mayors appointed not } \\
\text { elected }\end{array}$ & $\begin{array}{l}\text { Garo Pamboukian (2014-) } \\
\text {-Own data collection } \\
\text {-Additional security } \\
\text { measures }\end{array}$ \\
\hline
\end{tabular}




\begin{tabular}{|l|l|l|l|}
\hline Qalamoun & $\begin{array}{l}\text { Passive } \\
\text { (allow refugees to } \\
\text { use own networks } \\
\text { to integrate) }\end{array}$ & -Mainly Sunni & Talal Dunkir (2016-) \\
& & -No data collection \\
& & -Non-disbursal of \\
& & available resources \\
\hline
\end{tabular}

Table 2: Summary of empirical findings relating to municipalities in Lebanon.

\section{Turkey}

Since the declaration of an open border policy in June 2011, Turkey's ruling Justice and Development Party (AKP) government has adopted temporary protection regime for those fleeing war in Syria, providing the right to remain in Turkey, protection against forcible returns, and access to reception arrangements (Ineli-Ciğer 2014; İçduygu 2015). ${ }^{1}$ Although the institutional and policy frameworks for implementation of this regime are set out by the central government, they have had implications for adapted to the local-level governance, especially given that the overwhelming majority of refugees are in urban areas. ${ }^{2}$ On the development-side, this has required a focus on employment and public services (İçduygu and Diker 2017). On the security side, a series of terrorist attacks since 2013 has resulted in heightened border security measures (Çorabatır 2016; Öztı̆̆ 2016).

Reflecting the country's strong state tradition (Heper and Keyman 1998; Kubicek 2000), Turkey's response to Syrian refugees has had a centralised character. The local management of the refugee influx has been mainly undertaken by the state-appointed provincial governors and the provincial offices of relevant state agencies, such as the Directorate General of Migration Management (DGMM). Nevertheless, municipalities, the cornerstone of Turkey's local governance system, have been at the forefront of providing public services and support 
for the socio-economic integration of refugees (Callet-Ravat and Madore 2016; Erdoğan 2017; Woods and Kayal1 2017). However, their specific mandate towards refugees, or nonTurkish citizens broadly, remains vague. Consequently, the precise role of municipalities varies significantly across context. This variance manifests itself in the different degrees of solidarity shown by municipalities, ranging from minimal involvement to active engagement in supporting socio-economic integration of refugees. The degree of additional involvement can be rank ordered: Gaziantep, followed by Adana, followed by Izmir have been the relatively most active in offering supplementary support to refugees.

The elected metropolitan and district-level municipalities are the most autonomous and extensive local service providers in charge of meeting all common local needs in cities (Gül and Batman 2016; Demirkaya 2016). Through a series of administrative reforms since the early 2000s, metropolitan municipalities and their locally elected mayors have acquired extended responsibilities and increased resources (Joppien 2017). They are structurally constrained by two factors: the levels of authority and money delegated to them by the central government. First, the mandate and the political authority of municipalities concerning refugees are not formally laid out in the legislative framework. ${ }^{3}$ Second, there is no specifically delegated central government funding for refugees, which constitutes the primary revenue source of municipalities. ${ }^{4}$

However, as our research shows, there is some leeway for municipal authorities to act autonomously and offer supplementary support to refugees. Regarding legal mandate, proactive municipal authorities refer to Article 13 of the Municipality Law (No.5393) as the basis for municipal responsibility of delivering services to Syrian refugees. Without differentiating between citizens and foreigners, Article 13 defines any resident of a town as a fellow townsman [hemşehri], who has the right to participate in municipal decision-making mechanisms and services, and the right to get municipal aid. It also entitles municipalities to develop social and cultural relations among townspeople. To overcome financial constraints, actively engaged municipalities seek external funding through establishing partnerships with NGOs and international actors. On the agency side, the mayor's particular approach to the refugee situation, his/her own leadership and political will is also a determining factor in the overall municipal engagement with refugee politics. ${ }^{5}$ Although our primary focus is on metropolitan municipalities, district-level mayors may also exert such influence. 
As laid out in the theoretical framework, a key factor that constrains or enables the scope for municipal discretion in the Turkish context is party politics. To briefly contextualise, the Syrian refugee issue has taken centre stage in domestic political debates, drawing criticism from the main opposition parties especially in the run up to the 2014 and 2015 local, national and presidential elections. While the ruling AKP government has pursued both progressive and restrictive policies with its own continuities and shifts, Turkish hospitality and Muslim fraternity towards Syrian refugees have been the most prominent discursive themes among the party's elites (Kaya 2016; Erdoğan and Kaya 2015). The two main opposition parties, on the other hand, have used representations of Syrian refugees as a 'voter threat', a 'demographic threat', a 'rival group having unfair access to public services' in various circumstances and contexts (Ilgıt and Memişoğlu 2017). The centre-left Republican People's Party (CHP) has framed Syrians as a burden caused by the government's policies, while the nationalist-right Nationalist Movement Party (MHP) has securitised the issue in connection with the protection of territorial integrity and national unity. MHP also employs a recurring identity-based discourse in its response to the refugee problems, showing solidarity towards a specific ethnic group, the Turkmens. As will be discussed below, the constituency's political identity or mayoral partisanship can have direct effects on municipality's refugee policy.

\subsection{Gaziantep}

Located less than $100 \mathrm{~km}$ from the Syrian border, the local authorities of Gaziantep were among the first to receive refugee inflows and to set up camps in the surrounding districts. With the influx of self-settled refugees in urban areas from early 2012, the city's population increased by 20 per cent as of 2018 (DGMM 2018). Hosting nearly half a million refugees, several factors account for Gaziantep's popularity: geographical and cultural proximity to Syria, kinship ties, existing social and economic networks, the city's relatively strong economic profile in the region, and the overall local responsiveness. The city has also become a hub for Syrian entrepreneurs, who have set up more than 1000 enterprises. Business community representatives we interviewed consider Syrians' economic contribution positively, which they actively support by offering consultancy services, vocational courses and employment opportunities. ${ }^{6}$ 
Run by the ruling party AKP, the city's metropolitan municipality has been a prominent actor of the local refugee response from the early years of the crisis. Initially focused on providing basic humanitarian assistance, the municipality has adopted more formal mechanisms to meet the increased demand on services following Fatma Şahin's election as mayor in 2014. As a former MP from Gaziantep and Minister of Family and Social Policies, Şahin has been an influential politician, playing a leading role in AKP's local and national organisation since the early 2000s (Güneş-Ayata and Tütüncü 2010). She has also gained international recognition as the pro-refugee mayor of a city that has become a regional hub for humanitarian organisations involved in crisis management. In 2016, Şahin was elected as the president of United Cities and Local Governments for the MENA region. The same year, she got nominated for Nobel Peace Prize for her municipality's efforts in assisting Syrian refugees (Gotev 2018). Having previously worked as an engineer at Gaziantep's largest industrial group Sanko, her professional background also comes into play that she is supportive of presenting Syrians refugees as a potential development opportunity for the local economy. In her own words:

For 30 to 40 years, Gaziantep has successfully used immigration movements to benefit its economy. It has always been a growing city. Some citizens may be worried about their jobs, the economic struggles, the financial situation, because it has affected some businesses. The Syrian community established 700 factories here in Gaziantep alone. They have engineers, doctors and workers. The government is working to integrate Syrians into the Turkish economy. Our first three priorities are health, education and security, so we are working hard to integrate Syrians. We want them to be a part of this community in the long term (Milliyet 2016).

Our respondents from different municipal departments identified their engagement with the Syrian refugees as the 'Gaziantep model'. The mayor's organisational leadership and political experience, as explained by a municipal official, has enabled them to look beyond short-term fixes, and to develop mid-to long-term social policies in addressing challenges faced by refugees and the host community. ${ }^{7}$ These included setting up two schools for refugee children, a community support centre, and a specialised migration affairs unit under the municipality. Between 2014 and 2016, the number of refugee children enrolled in schools increased from 3000 to 70,000 in collaboration with the national education authorities. ${ }^{8}$ To overcome housing shortages, the municipality established a partnership with the national housing 
authority (TOKI) for the construction of a mass housing project for 250,000 people (Milliyet 2017). Syrian refugees are also able to access existing services, including the municipal hospital and the domestic violence shelter for women. In 2016, over 3000 Syrians were attending courses at the municipality's vocational training centre. ${ }^{9}$

Located in the mixed Turkish-Kurdish-Arabic district of Narlitepe, the municipality's community centre provides consultancy services up to 400 Syrians weekly. Social workers explained that they also use sports, arts and cultural activities held at the centre as tools to boost social interactions between refugees and the locals. However, a growing challenge for the municipal authorities is finding effective integration strategies: 'Syrians move often in search of cheaper housing. They don't stay long enough to establish lasting relationships with the locals. And we don't have the financial means to open a community centre in every neighbourhood'. ${ }^{10}$ In order to reach out to a wider refugee community and to foster their participation, they have introduced a practice where refugees are able to elect 'refugee representatives' from their neighbourhoods. ${ }^{11}$

The municipality has also sought international assistance to cover its tailored capacity needs. While UNICEF and IOM contribute to the running costs of the community centre and the schools, the municipality gets capacity-building assistance on waste management recovery as part of a $\$ 3$ million UNDP project (UNDP 2017). Setting up the first specialised municipal migration unit in Turkey, according to its director, has helped them to establish transnational ties and mobilise more resources:

International organisations feel uneasy about partnerships with state institutions due to bureaucratic rigidity, so they come to the municipality first. Municipalities are more flexible, but they often lack qualified staff to engage with international actors. Also, certain stereotyping and mistrust issues come to surface; their good will towards Syrian refugees is often questioned. But it is important to overcome such prejudices, because at the end of the day our budget is limited. Collaborating with international partners is a win-win case, this is how we see it, and our common goal is to offer better services. ${ }^{12}$

\subsection{Adana}


As a major agricultural and industrial centre in southern Turkey not far from the Syrian border, Adana has also become a preferred destination for over 200,000 Syrian refugees (DGMM 2018). Aside from the large job market, kinship relations with the local Arab population and the municipality's aid to Turkmen refugees have also been key pull factors. In contrast to Gaziantep where Syrians are dispersed across the city, the refugees are concentrated almost exclusively in certain neighbourhoods of the two central districts, Seyhan and Yüreğir. According to the local authorities, refugees have created new segregated 'Syrian enclaves' or absorbed into 'existing neighbourhoods of immigrant communities', which limits their social interaction with the overwhelming majority of locals. ${ }^{13}$ Although many refugees have set up small-scale businesses in these neighbourhoods, business representatives viewed their impact on the local economy as 'not too significant or visible' as there were less than 120 registered Syrian enterprises. ${ }^{14}$

The local government represents a mixture of political parties: the metropolitan municipality is run by MHP, while Seyhan and Yüreğir district-level municipalities are run by CHP and AKP, respectively. At the time of fieldwork, none of these municipalities had specialised institutions for refugees; however, they were all providing formal and informal assistance to varying extents. ${ }^{15}$ The Seyhan district municipality (CHP), for instance, provided short-term employment for 200 Syrian refugees and 200 Turkish citizens in its parks and green spaces, as part of a livelihoods project in partnership with the UNHCR and GIZ. Seyhan's district mayor, Zeydan Karalar, has been particularly vocal about municipal responsibility to protect refugees and the need for additional government funding despite his party's general disengagement from the Syrian refugee issue (Milliyet 2016). ${ }^{16}$

The metropolitan municipality, on the other hand, has adopted a 'selective solidarity' approach in its engagement with refugees, reflecting the MHP's pan-Turkist nationalism (Çınar and Arıkan 2002). They removed Arabic signs from several Syrian shops 'in order to protect the Turkish language', for instance (Hürriyet Daily News 2017). Municipal officials asserted that their informal assistance has primarily targeted the needs of refugees that 'they have common kinship with', most notably Turkmens coming from Syria and Iraq. ${ }^{17}$ The municipality practice is also influenced by its incumbent mayor. Hüseyin Sözlü has been a locally rooted politician from MHP, who has served as a district mayor since 1999 until his election as the metropolitan mayor in 2014. Supporting the Turkmens has also been central to his discourse: 'Our party has been the greatest supporter of Turkic world and our leader 
Devlet Bahçeli has always been on the side of Turkmen people. For our nation's future, we are also ready to support Turkmens in every possible way' (Milliyet 2017a). Since he took office, the municipality provided temporary shelter to nearly 500 refugees in its guesthouse: 'around 90 per cent of the arrivals were Turkmens, but of course there were Arabs, too. We never asked whether they were Arabs or Turkmens' ${ }^{18}$ At later stages, the municipality's social media accounts were used to mobilise the public in helping refugees to find permanent housing.

Through establishing transnational networks with Turkmen associations in Syria and Iraq, the municipality has also delivered water, medical equipment across borders, and built a hospital in rural Latakia in cooperation with Turkish Red Crescent. Emphasizing that these initiatives were covered from the municipal budget, an official commented: 'Gaziantep's municipality is helping the reconstruction of Jarablus, they are providing water and electricity. And this is covered by state allocated funding. In our case, the budget is limited, we do not know if we can get such additional funding. It is related to political dynamics'. ${ }^{19}$ When asked whether the municipality had any plans to formalise its services for refugees living in Adana, the officials pointed at legal and budget restrictions concerning municipalities, and their sensitive political position as the representatives of an opposition party: 'It is hard for us to deliver any permanent services, we need to think twice. It is mainly through our personal efforts that we help refugees so that they can begin to normalise their lives' ${ }^{20}$

\subsection{Izmir}

Situated on the Aegean coast, Izmir has been a long-standing transit and departure point for migrants en route to Europe (Crawley and Özerim 2016). During the peak of the refugee crisis in 2015 , it is estimated that over 300,000 refugees have transited the city within a few months, putting the issue in the public spot (Tan 2016:80). The city's settled Syrian population has also grown threefold in three years, reaching 140,000 as of 2018 (DGMM 2018). The presence of a large Kurdish immigrant population also attracted Syrians of Kurdish origin to the city (Y1ld1z and Üzgören 2016: 201).

At the time of fieldwork, it was mainly district-level municipalities and a number of newly emerging local NGOs that were offering supplementary support to refugees in Izmir. Meanwhile, the CHP-run metropolitan municipality took a relative passive role. It regarded 
the arrival of Syrian refugees mainly as a transit problem, with Syrians using the city as a means to access the Aegean Sea and reach Europe. In the words of a local NGO representative, the municipality has been very consistent in its response from the early days of the crisis: 'whoever brought them here, should also take care of them'. ${ }^{21}$ As the longest serving mayor in Izmir's recent history, Aziz Kocaoğlu receives wide public support for providing well-established urban services, for active engagement with citizens and for pursuing an inclusive social policy towards disadvantaged groups. ${ }^{22}$ In 2014 , he was named among the 'Top-10 Mayors in the World' by the London-based organisation City Mayors Foundation. However, refugees have not been a priority on the municipality's policy agenda. ${ }^{23}$

As a traditional electoral stronghold of the main opposition party, municipality's disengagement with the Syrian refugees mirrors the CHP's consistent criticism of the government's Syria policy. Several NGO workers stated that their attempts to engage the municipality have been rejected on political grounds: 'the most common narrative you hear is that "Syrians are here because of AKP's wrong policies. It is a heavy burden on all of us. State institutions should take care of them, it is not our responsibility". ${ }^{24}$ An often-cited example is the municipality's refusal to include Syrian refugee children into its 'Milk Lamb [Süt Kuzusu]' project, which has been running in Izmir since 2005. ${ }^{25}$ 'We first brought this to the attention of municipality in 2009 for other smaller group of refugees. We raised it again for Syrian refugees. They were saying "the legislative framework is not appropriate". The city hosts over 100thousand refugees now, but we still get the same answer'.

According to the municipal officials we interviewed, the legal framework does not allow them to assist Syrian refugees directly. If they are granted a permanent legal status, this situation might change. 'The needs of Syrian refugees are fundamentally financial and material', one official added, 'this is why they do not come to the municipality for assistance, they go to the DGMM or to the governor's office instead'. ${ }^{26}$

Representatives from district-level municipalities of Konak and Karabağlar (also CHP), referred to the metropolitan municipality's stance as 'self-isolating' when all civil society actors in Izmir were mobilising resources to support the city's growing Syrian population. The two district municipalities, which together hosts nearly 70 per cent of the urban Syrian refugees, offer Turkish language courses and consultancy services. In order to engage 
refugees into their decision-making mechanisms, they have jointly established 'a refugee assembly' bringing together representatives from local Syrian NGOs.

Some respondents drew attention to the fact that metropolitan municipality's disengagement also fitted well with the general public perception that Izmir should not become a point of attraction for refugee settlement. In the words of a national NGO worker: 'Syrians in Izmir were mainly disregarded until the arrival of thousands of transiting refugees in 2015. Izmir is a charming city with a thriving tourism sector and Western outlook. No one wanted the city to turn into a "refugee city", especially the municipality and the business sector. Public institutions and the civil society have been more receptive from the beginning, but the municipality did not adopt any inclusive policies'. As a matter of fact, local business representatives we interviewed were not certain if there were any registered Syrian enterprises in Izmir, indicating their lack of interest in refugees' economic contribution in contrast to Gaziantep and Adana. ${ }^{27}$

Nevertheless, the implementation of the EU-Turkey agreement from March 2016, which largely curbed irregular migration flows via Izmir, has been a critical turning point for local actors to start acknowledging that the city's remaining Syrian population are there to settle, followed by the opening of the first temporary education centre in 2016. Some other steps followed, such as the Metropolitan Municipality's decision to include Syrian refugee children into their milk assistance programme in early 2017 and several social cohesion activities they have jointly organized with NGOs. In the words of the head of Karabağlar Municipality City Council, 'we became quite obsessed with the Municipality's resistance to not include Syrian refugee children into its milk programme. We tried to prove that not all locals of Izmir or CHP voters are anti-refugee, because it was the municipality's major concern, not to terrify its electorate by supporting refugees. The petition campaign we started got more than 200 civil society representatives on board, including the most nationalist and secular ones. And they finally gave in'. ${ }^{28}$

\section{Lebanon}

With over 1 million Syrians, Lebanon hosts proportionally more Syrians than any other country. In some municipalities Syrians outnumber Lebanese by three to one. During interviews, most government officials acknowledged that they were unprepared for an influx 
so large and a conflict so protracted.

Lebanon did not sign the 1951 UN Convention on the Status of Refugees. Syrians are dealt with through legislation afforded to Syrians generally, referred to as 'displaced' and not as refugees (Janmyr 2017). Until October 2014, bilateral agreements signed in 1991 and 1993 governed the reciprocal movement and presence of Syrian and Lebanese citizens. They guaranteed a range of rights for Syrian and Lebanese citizens, and created a common market implicitly favouring Syria. They included freedom of movement, of stay, of employment, investment, transportation and transit, between both countries. ${ }^{29}$ This open-door policy was 'de-facto' because it simply maintained existing regulations (Mourad 2017), allowing UNHCR and other agencies to deal with Syrians in a way akin to 'indirect rule' (Mourad 2017). 'Non-encampment' continues, partly because of fears that formally established Syrian camps could become powerful political challengers in Lebanon like the Palestinian camps did historically, and partly because non-encampment benefits economic interests in the country (Turner 2015).

National policies were "standoffish" (Mourad 2017) with implications for municipalities. A 'Standoffish' state is disinterested in monopolizing authority in the Weberian sense, and in imposing legibility and standardization (Scott 2015). Standoffishness appeals to states which are primarily concerned with maintaining power whilst minimizing the political challenges which homogenization or monopolization efforts could provoke (Slater \& Kim 2015).

From 2011-2014 a policy of 'indirect rule' and absent leadership from the central government encouraged international agencies to bypass government institutions. In many places humanitarian organisations dealt directly with Syrians in the makeshift camps in which many resided. Only later did they systematically approach municipalities, and gradually the central government attempted to shift responsibility for Syrians onto municipalities.

The main national policy was the 2014 October Policy, stating that security forces will implement measures to 'control the security of the displacement'. In addition to entry and residency restrictions, it commissioned municipalities to conduct periodic censuses of Syrians, and said that municipal police will be provided with the necessary elements for maintaining security. Municipalities have shaped variations in the October Policy's implementation. Prior to the policy, the Ministry of Interior and Municipalities (MOIM) encouraged municipalities 
to take a leading role in security controls, while publicly questioning the legality of their actions (Mourad 2017). In September 2013, the MOIM, after meeting with over 800 municipalities and Municipal Unions, enacted a plan calling for: the arming of municipal police and for their joint patrols with the Internal Security Forces (ISF) under the authority of Mayors and heads of security, and for confiscating Syrians' documents and overseeing aid and assistance (MOIM Circular 11/09/2013 in Mourad 2017). ${ }^{30}$ There was no oversight over the exercise of these powers, and only with a Mayor's approval would national security forces pursue municipal police in relation to their actions. There was no mention of discriminatory actions like curfews, arbitrary detention and document confiscations (Mourad 2017). Lebanese human rights group ALEF expressed concerns that this would encourage ad hoc measures by municipalities with protection implications (ALEF 2013:25).

Adequate funds for this problematic plan have not arrived for chronically underfunded municipalities (Harb \& Atallah 2015). Fees on rental value of built real estate, construction permits and sewerage and pavement maintenance, are the only three directly collected fees of financial significance, forming $83 \%$ of revenues in 2008 . Thirty-three other fees constitute $17 \%$ of revenues; municipalities may not legally establish new tariffs or taxes (Ibid). Nor do they have enough tax collectors or mechanisms to enforce outdated tax formulas: collection averages 50\% (Ibid). Transfers earmarked from the Telecommunications tax have not been disbursed since 2010 (Mourad 2017).

Mayors operate against this backdrop. The next section is based on interviews with Mayors and municipal representatives of Hawsh-Musa (Anjar), Zahle-Malaqa-Ta'nayel, and Qalamoun, ${ }^{31}$ illustrating the different extents to which Mayors can make a difference. Zahle is the most tolerant of refugees. Qalamoun is fairly passive with little additional proactivity or restriction. Anjar is hospitable to Armenian Syrians but imposes security restrictions on other Syrians.

\subsection{Zahle}

Zahle - Maalaqa - Ta'nayel municipality (henceforth Zahle) is $18 \mathrm{~km}$ from the Masna' eastern border crossing to Syria. It is predominantly Christian and the city of Zahle is Lebanon's fourth largest. Known for its vineyards from which wine and arak are produced, its pleasant environment and climate, it is a tourist destination for Lebanese and Syrians. 
Zahle does not experience power-cuts - rare for Lebanon; the region has its own electricity supplier Energe de Zahle which serves 250,000 people in the municipality and beyond (Najib 2016). Zahle's recycling plant opened in 2007. It does not suffer from garbage crises which plagued the rest of the country, instead charging other municipalities to process waste (Bluhm 2007).

As'ad Zoghaib, is an engineer by training and has been Mayor since 2016, but also between 2004-2010 when the recycling facility opened. Zoghaib acquired international funds to support refugees from the World Bank, the IMF, and USAID. His connections introduced an international element to Zahle's funding and development which arguably should have been something paid for by the central Lebanese government. Zoghaib's re-election was as head of the "Zahle Development List" endorsed by numerous parties, running on a campaign to further develop Zahle, keeping its environs pleasant for locals and tourists.

The Mayor matters in Zahle: he is respected, utilising international connections to improve infrastructure. But with the Syrian influx, the support he requires from the central government, to deal with a $47 \%$ population increase, is absent. The local population is 150,000. Additionally, 60,000 Syrians live in tents, and 20,000 live in central Zahle. Unlike his predecessor, Zoghaib counts refugees by municipal census. The previous incumbent relied on numbers from international organisations, the Ministry of Social Affairs, and jamiyaat charities working with Syrians. Syrians were present in Zahle as seasonal or circular labourers, typically for 6-month periods. He somewhat feared this this larger presence. '[If armed] ... it would only take 5,000 of the 20,000 Syrians in Zahle to take over.'

Zoghaib uses data pragmatically to respond to and seek international support for refugees. The previous Mayor seemed uninterested in managing the Syrian influx. Zoghaib showed us a map of the camps with municipal boundaries which the municipality made using data from UN agencies. Zoghaib is frustrated that the central government does not regulate the tented settlements, for example to ensure a minimum distance between tents in case of fire, and to ensure that water and waste are properly addressed. 'The central state is dumping its problems on municipalities'; he explained that sewage and solid waste collection are national issues for which the central state shifted responsibility to the municipalities. 'With the Syrian issue, the problem differs, but is similar in terms of central state responsibility.' Zoghaib was concerned about public health and safety in the camps as overcrowding was common. But 
'municipalities do not have leadership from the central state, so each has its own policy, there is no consistent system'. They are not given adequate resources either: 'We have a tax structure: a percentage for street lighting, specific services, collecting garbage, sweeping the streets. But there isn't a percentage for processing garbage. Where am I supposed to get this from?'

When Zoghaib's previous term ended in 2010, the municipality dealt with 160 tons trash daily. The Syrian influx means it is now 360 tonnes. Initially, UN and other agencies bypassed the municipality, dealing directly with Syrian camps. The municipality suspended trash collection from camps to gain their attention. They subsequently approached the municipality and agreed to contribute towards municipal costs. Zoghaib rejects proposed projects that only benefit Syrians.

The municipality does not deal directly with Syrians, except for the Shaweesh, the person in charge of informal Syrian camps. The municipality does not issue ID cards but asks employers who hire Syrians to register Syrians using their IDs. But Zoghaib chooses not to interpret the October 2014 Policy as requiring curfews for Syrians. He said "to forbid a man who lives in a tent and works all day, and wants to walk in the evening near the Bardowni [river] with his wife [is] not reasonable."

\subsection{Qalamoun ${ }^{32}$}

Qalamoun municipality lies 5km south of Tripoli, Lebanon's second largest city and port, and $40 \mathrm{~km}$ from the Syrian border. The majority Sunni population lives beside a small Christian minority. Rents are lower than in Tripoli or Beirut. Syrians have worked and intermarried with Lebanese in Qalamoun for years.

Qalamoun's Mayor, Talal Dunkir, matters a lot but for the wrong reasons. According to a current member of the Municipal council, Dunkir's inactivity causes inertia in the municipality: 'A Municipal Council in Lebanon is a reflection of its Mayor, if he is active, the Council will be active.' The Mayor can spend up to $\$ 2,000$ from the municipal budget without approval from the Municipal Council, including for overtime. We did not hear of such funds being disbursed to alleviate pressures from the Syrian presence, but it is common for the Mayor to pay overtime to favoured staff without needing the Council's approval. 
Qalamoun's story is one of a municipality with untapped potential. It has tourism potential from its coastal resorts, and has businesses including pickle and salt factories which, he said, are not being charged proper business fees. Accordingly, the Municipal building itself is unimpressively small and tired looking, unlike others of comparable municipal size.

Qalamoun's pressures are similar to those of other municipalities': increased waste water and solid waste loads, competition in the labour and small trade market, and on accommodation. The municipality did not produce statistics about Syrians - perhaps caused by the Mayor's apparent inertia. They relied on numbers from local charities and NGOs - jamiyaatworking with Lebanese, and more recently Syrians. However, Syrians rarely tell the jamiyaat upon leaving Qalamoun; the jamiyaat lack the capacity to follow up on its rudimentary paper records.

Some Syrians worked in Qalamoun for many years in construction and stone masonry and Syrian-Lebanese intermarriage was common. After 2012, many brought their relatives to join them from Syria. At first the jamiya did not register them all as nazihin - the Council member used the word 'displaced' rather than refugees (lagi'in). But later it was necessary for Syrians to seek aid with living expenses. The jamiya has three tiers of those in need: orphans, the disabled and their carers, and large families with no bread-winner.

They estimate that 6,000-7,000 Syrians lived alongside the same number of locals. The organisations and NGOs worked independently of each other, some received support from INGOs and International Agencies including UNDP. These organisations, not the municipality, supported projects like creating a nursery, a park, and a school. But planning only included Lebanese and international organisations, and not Syrians. Syrian children attend the local school during a second shift. In Qalamoun, international agencies approached the municipality before engaging in projects, unlike elsewhere where they initially dealt directly with Syrians.

Furthermore, there is an absence of comprehensive coordination with the array of active aid organisations. The Council member we interviewed was concerned that the lack of coordination risked project duplication but did not name specific incidents. Among the projects which aid organisations had helped with were: repair of a water well (Danish Refugee Council), water and sanitation projects (OXFAM), limited healthcare provision 
(UNHCR, CARITAS), assistance to disabled families (HANDICAP). OXFAM provided food vouchers for 1700 families and clothes vouchers for 500 children, worth around US\$300,000. They were valid in different stores in Qalamoun, distributing local benefits widely, unlike elsewhere where only a few stores benefited, creating tensions. The municipality influenced this decision to prevent tensions.

The Municipal government is 'standoffish' towards Syrians, like the national government. The result is that it makes no attempt to obtain its own data about Syrians, nor to regulate their presence. Syrian stalls have popped up near municipal fee-paying Lebanese businesses, much to their annoyance. One informant explained that:

Syrian stalls can undercut local businesses because their costs are lower and they do not pay fees. Of course they must work and have an income, we don't want a person stealing to survive. ... But the municipality should regulate this: why not have a rule preventing a Syrian competitor opening a stall close to an established Lebanese business? It can do this but it does not. $^{33}$

At the time of interview, central government regulations required Syrians to pay an annual \$200 residency charge. Our Municipal participant believed the central government used this to send a message that they had had enough of the Syrians. He disagreed with it, approving more of the integrative policies of the Turkish government, but he has no power to influence this decision. There was a disconnect between the municipality and the central government in terms of how up to date they were with residency regulations of General Security: the administrator still referred to old rules regarding GS' demands for Syrians to acquire a rental support document from the municipality. There have been no curfews here, only some rules regarding noisy motorcycles.

\subsection{Anjar ${ }^{34}$}

Anjar, is an Armenian village in the Beqaa $2 \mathrm{~km}$ from the Masnaa border-crossing to Syria. Its official name is Hawsh Musa, but its residents refer to it as Anjar, as does Mr. Garo Pamboukian, its Mayor from 2010-2016. It is not to be confused with Majdal Anjar, adjacent to Masnaa. The municipality has parochial and transnational currents linked to its Armenian history, influencing its Syrian policies. There are 3,000 Anjaris, and 13,000 Syrians. Anjar is 
a composite Arabic-Syriani name meaning 'the flowing spring'. Municipal attention to the environment attracts tourists to Anjar. Tourism income from Syria fell sharply after 2011, reducing the income from tickets to the Citadel from $\$ 133,000$ (LL 2 million) p/a to less than $\$ 17,000$ (LL25m) p/a, of which the municipality receives half. During the Syrian occupation, Syrian Military Intelligence was headquartered in Anjar. Many Lebanese citizens were tortured and 'disappeared'. The name aroused fear and the municipality sought to transform it into a place associated with tourism and prosperity. Unusually for Lebanon, it has a privately run uninterrupted electricity supply.

Early in the crisis, aid organisations ignored the municipality, giving aid directly to refugees, adding to the litter problem and neglecting vulnerable Lebanese. When organisations began working with municipalities, Garo refused to deal with any that were ignoring vulnerable Lebanese, and any imposed conditions on aid. 'They wanted projects that focused on social cohesion but we ... are a minority in Lebanon and want to maintain our distinct identity.' The municipality formed a committee to assist Syrian Armenians, to find aid from international organisations that did not impose conditions. The only successful fit was a solar energy project from the IOCC. 'On paper it is written as if it serves Syrians and us, but in practice it's only us.' Anjar has no public schools, but the private schools hosted Syrian Armenians using financial support from the church organisations with which each school is affiliated.

Farming land in the Beqaa became less profitable after the loss of the Syrian market. Landowners subsequently rented land to Syrians to use as camps: the municipality could not enforce its permit policy and several camps emerged. 'But what will it do to neighbouring properties, and the electricity lines? And what do they care about the garbage or sewage going into the river?!' The municipality refused to grant permission for an NGO to build water storage tanks for informal camps, Garo referred frequently to the effects on property and land.

The municipality viewed the absence of a central state policy towards Syrians negatively. They resisted calls to register refugees at the municipality in response to the MOIM's September 2013 security plan. 'Not every foreigner is a refugee!' exalted Garo, referring to the pre-2011 presence of Syrian labourers. 'A refugee has rights. If we give that status, it comes with great responsibilities.' However, they had their own records of Syrians. Syrians were present in Anjar as labourers before the Syrian uprising: Garo did not consider Syrian 
labourers with jobs to be refugees deserving of international assistance. Before 2011, there were 3,000 Syrian labourers in Anjar: 'We know this because we registered their names, addresses, owners of the properties where they lived, employers' names and had their fingerprints'. The 'Republic of Anjar' did not take a standoffish approach to the Syrian population in the same way that the central government did (Mourad 2017): they wanted to make Syrians legible, to see like the state of Scott's conception (1998). When the central state enacted the 2014 October Policy, and before the MOIM's 2013 security plan, Anjar's municipality already held meticulous data. After the MOIM plan, seven contracted municipal policemen were added to the five based in Anjar. 'You tell us we can hire more police but how am I supposed to pay them? Here, we have them running 24 hours, three eight-hour shifts with four on each shift. We also installed cameras and an observation room costing $\$ 50,000$.' The additional staff are to control the increased Syrian population, but more significantly to patrol the borcer in addition to the Lebanese Armed Forces (LAF). Interestingly, he referred to a 'Self Defence' group to protect the area; we assumed that the Armenian Tashnag party provided this. They handed any captured infiltrators to the LAF. Anjar imposed a night curfew for motorbikes, from 7pm-7am, applicable to all 'foreigners', not only to Syrians. Additionally, Garo referred to a 'dark room' at the Municipal Police station where Syrians were disciplined. He claimed this practice was widespread.

The Central Authority of the Tashnag Party - The Armenian Revolutionary Federation, with Regional and Global decision-making Committees, appoints Mayors in Anjar. Garo joked about “The Republic of Anjar” owing to Anjar's autonomous 'one party rule.' (Diab 2012). Tashnag is Lebanon's main Armenian political party, but is connected to Armenia and the Armenian diaspora. In this sense, the municipality is transnational with interests beyond Lebanon's borders. Signs and graffiti around Anjar condemn the Turkish genocide. Tashnag is an Armenian nationalist organisation and currently part of the March $8^{\text {th }}$ bloc which includes the Free Patriotic Movement and Hezbollah. The Mayor does not always obey Tashnag. When the central government wanted to create a waste landfill site in Masnaa', Tashnag approved. Mr. Pamboukian and his constituents rejected the offer of $\$ 50$ per tonne of waste, fearing polluted water and the consequences for tourism. Anjar and neighbouring Majdal Anjar belong to The Union of Municipalities of Central Beqaa, the head of which is Majdal Anjar's Mayor, Sami Al-Ajami. The local populations, coordinating with neighbouring Majdal Anjar, successfully opposed the landfill site, partly by protesting on the 
highway, threatening to block an important Lebanese economic artery. This trans-municipal cohesion was absent in refugee policies where each municipality acted independently.

Selective solidarity emerged in Anjar, which is both transnational and parochial in its outlook. 'Everyone who is not from Anjar is like a foreigner, even the Armenians from Beirut and Zahle.' The municipality showed different levels of solidarity towards Syrian Armenians, influenced by different currents: the desire to help Armenians in need, the nationalist desire to maintain an Armenian presence in Syria, and the desire to keep Anjar for Anjaris. The municipality decided not to become a general refuge for Syrian Armenians, only to make an exception if they arrived as part of a mass displacement. But this was unenforceable. A local priest refused to turn an Armenian family away. 'We still have 100 families here in total.'

From Dera came 300 Armenian Syrian families. Later came Armenians from Aleppo. Rents increased: a house that cost $\$ 100$ a month soon cost $\$ 500$. When their savings dwindled, Syrians competed in the labour and small business market. Many sought work in Beirut, others were resettled to Canada and Australia. The Armenian Church did not support the municipality as it opposes any depopulation of Armenians from Syria, Iraq and Lebanon. Armenians who immediately fled Kassab to Lattakia in March 2014 after Al Nusra forces took over were not warmly welcomed in Anjar. Armenians from Aleppo and Dera did not flee straight away and tried to remain. Kasab's Armenians, from the same area in contemporary Turkey as are Anjaris, did not resist Al Nusra and this angered Anjari Armenians. Kassab is symbolically significant to Armenians because of its church and their historical presence. 'We told Kassab's Armenians that they must return to Kassab as soon as it is liberated. ... But we encouraged our people to open their open their doors and not charge rent.'

\section{Conclusion}

We have explored how mayors make a difference to refugee policy; the ways in which they mediate the implementation of national policies or develop additional, supplementary policies and practices at the municipal level. In order to do so we have comparatively examined municipal level responses in the two most numerically significant host countries for the Syrian refugee crisis: Turkey and Lebanon, collecting qualitative data in a total of six different municipalities. 
Although not intended to be representative of the national or regional context, we selected the cases because they enabled us to explore potentially salient sources of variation, notably in terms of the political identity of each municipality, as indicated by the dominant political party in Turkey and by confessionalism in Lebanon, where mayors generally do not run on party lists. Our goal has been to engage in theory-building rather than theory-testing; to develop a heuristic framework based on comparative analysis, which might then be tested more widely. The primary aim of our heuristic framework is to enable the disaggregation of variables sufficiently to isolate the independent effect of mayors themselves from wider structural influences. Put simply, we wanted to know whether mayors qua mayors make a difference, or whether the wider political context of the municipality determines outcomes.

Empirically, the cases for each country broadly hold constant the constitutional relationship of the municipality to central government. In both Turkey and Lebanon, municipalities are not provided with additional resources to support refugees, and nor are they delegated significant authority vis-à-vis refugee affairs (albeit with some differences between the countries). The main source of structural variation between the cases relates to constituency identity. The political party that controls the metropolitan municipality in Turkey (AKP, MHP, or CHP) influences the likelihood of providing supplementary services. Meanwhile, the dominant confessional identity of the municipality in Lebanon (Sunni, Christian, Armenian) influences the type of solidarity shown.

However, beyond difference within the municipal authorities, the agency of particular mayors also makes a difference to policy outcomes. This additional difference can be assessed counterfactually: how would outcomes have been different if the incumbent mayor had not been in office? In Gaziantep, for example, one would expect any AKP mayor, faced with relatively positive economic circumstances to try to support a refugee inclusion agenda. Some of the initiatives - like drawing upon personal networks to approach international organisations for direct support, or establishing a metropolitan migration unit - have relied upon Fatma Şahin's own social capital and leadership. Similarly, in Zahle, one might expect a relatively prosperous and predominantly Christian area to be tolerant of Syrian refugees. However, without As'ad Zoghaib in power, it seems unlikely that there would have been attempts to build municipal-level data relating to refugees or to form direct relationships with international organisations. Zoghaib was also very explicit in having a personal conviction that implementing the central government October Policy's curfews would be inhumane. These particular mayors also have in common transnational networks, including to UN 
organisations, which have enabled them to attract additional resources in support of progressive refugee policies.

Comparative analysis, however, shows that there is nothing inevitable about a particular mayor translating a relatively auspicious structural context into more progressive outcomes. Qalamoun, for instance, is a mainly Sunni municipality in which the host community have long been tolerant of the presence of Sunni Syrians. In contrast to Zoghaib, mayor Talal Dunkir has not engaged in municipal data collection, has not built independent relationships with international organisations, and has not even disbursed available resources that he could have allocated to enhance refugee integration. In that sense, the structural political context of the municipality clearly makes a difference to whether and how far policy outcomes can be more or less proactive, or more of less restrictive, than central government policies. But individual mayors also have the agency to interpret these structural constraints, and to choose whether and how far they implement restrictive or progressive central government policies or adopt supplementary municipal policies, whether they be more tolerant or more restrictive (as in the case of Anjar, for example).

These findings matter for wider academic work. First, we extend the empirical scope of the growing literature on the role of cities in world politics to include the hitherto academically neglected domain of refugees. Second, our analysis contributes to the theoretical development of that literature by conceptually and methodologically distinguishing the role of the municipal-level of governance from the role of the mayor as actor. Third, we contribute to the literature on refugee politics by demonstrating the relevance of both mayors and the municipal-level of governance for understanding refugee policy outcomes and impacts.

Our findings also have policy relevance insofar as they highlight the importance to refugee policy makers of working with mayors and other municipal actors, whether to shape implementation of national government policies, to bypass the central government and promote more progressive outcomes, or to mitigate the effects of locally restrictive policies. Crucially, our framework suggests that there are a variety of intervention points available to shape these municipal outcomes, including understanding and influencing structural constraints such as the central government-municipality relationship and constituency identity, as well as routinely analysing the profiles particular mayors and offering progressive mayors access to transnational support networks such as the Global Mayoral Forum. In order 
to be effective, international public policy-makers working to promote refugee protection must engage with politics. That politics does not just take place at the national level but also the local level, and that includes a significant role for municipal authorities and mayors.

\section{Notes}

${ }^{1}$ Turkey maintains a geographical limitation to its ratification of the 1951 UN Convention on the Status of Refugees. Syrians were granted temporary protection status within the framework of the Law on Foreigners and International Protection (LFIP), which sets out four international protection categories: refugees (from Europe), conditional refugees (from outside of Europe), subsidiary protection and temporary protection (for mass influx situations).

2 The current non-camp population is less than 8 per cent of the total 3,5 million Syrian refugees residing in Turkey (UNHCR 2018).

3 The LFIP does not specifically address the duties of municipalities in migration management; however, it stipulates that the Directorate General of Migration Management (DGMM) may seek 'suggestions and contributions' of local governments concerning social harmonization (Article 96).

4 Interview, Union of Turkish Municipalities, Ankara, December 2016.

5 Ibid.

${ }^{6}$ Interviews, Chamber of Commerce and Chamber of Industry, Gaziantep, October 2016.

7 Interview, Municipality Migration Affairs Unit, Gaziantep, October 2016.

8 Ibid.

${ }^{9}$ Interview, Municipality Vocational Centre (GASMEK), Gaziantep, October 2016.

${ }^{10}$ Interview, Municipality Ensar Community Centre, Gaziantep, October 2016.

${ }^{11}$ Interview, Municipality Migration Affairs Unit, Gaziantep, October 2016. A similar mechanism is also implemented for camp-refugees in state-run camps.

12 Ibid.

${ }^{13}$ Interviews, Provincial DGMM, Adana, December 2016.

${ }^{14}$ Interviews, Chamber of Commerce and Chamber of Industry, Adana, November 2016.

${ }^{15}$ Yüreğir District Municipality was also providing food and coal assistance to the refugees living in their district.

${ }^{16}$ Interview, Seyhan District Municipality Social Services Unit, Adana, January 2017.

${ }^{17}$ Interviews, Metropolitan Municipality Health and Social Services Unit, Adana, November 2016.

${ }^{18}$ Ibid.

19 Ibid.

${ }^{20}$ The metropolitan municipality has recently adopted a more proactive role. In early 2018 , it established a migration affairs unit, similar to the 'Gaziantep model' and set up a refugee assembly through a joint initiative with the city council. In a follow-up contact with the municipality in March 2018, officials pointed at 
municipality's need to systematise its refugee policy in order to receive external funding given the growing presence of international organisations in Adana. This shift could also be attributed to the broader political context, since AKP and MHP leaders have recently announced that they formed an alliance for the upcoming presidential elections in Turkey.

${ }^{21}$ Interview, Izmir, December 2016.

${ }^{22}$ Ibid.

${ }^{23}$ Municipality's 200-pages long strategy document for 2015-2019 does not address any policies concerning refugees or migrants.

${ }^{24}$ Interviews, local NGO and national NGO representatives, Izmir, December 2016.

${ }^{25}$ Registered families with children aged 0-5 years receive weekly milk assistance from the municipality.

${ }^{26}$ Interview, Metropolitan Municipality Social Projects Unit, Izmir, December 2016.

${ }^{27}$ Interview, Chamber of Commerce, Izmir, December 2016.

${ }^{28}$ Interview, Izmir, December 2016.

${ }^{29}$ The Fraternity, Cooperation and Coordination Treaty was concluded between Syria and Lebanon on 22 May 1991 and complemented by The Agreement for Economic and Social Cooperation and Coordination 16 September 1993.

${ }^{30}$ Circular from Ministry of Interior and Municipalities to Governors, "Recommendations Related to the Operation of Municipal Police Taken during the Biel Meeting of 5 September 2013," 11 September 2013, in Mourad (2017: 264).

${ }^{31}$ We are grateful to Dr. Lama Mourad for her collaborative presence during all three of these interviews and to Mr. Norair Boutchakjian for his assistance and support during interviews in Anjar and Zahle.

${ }^{32}$ This section is based on interviews with an administrator employed at the Municipality, and with a member of the Qalamoun Municipal Council, elected in May 2016. The Council member is also a founder of a local charity organisation established in 2010, working with Lebanese, and more recently with Syrian residents.

${ }^{33}$ In Tripoli, we learned that the Municipality was having similar problems with informal Syrian street stalls in undesirable locations, but the Mayor explained that only the Ministry of Finance could tax them. Instead Municipal Police moved them on elsewhere.

${ }^{34}$ This section is based on an interview with the former Mayor of the Hawsh Mousa - Anjar Municipality, Mr. Garabet (Garo) Sarkis Pamboukian conducted in October 2016.

\section{REFERENCES}

1. Acharya, A. (2004) 'How Ideas Spread: Whose Norms Matter? Norm Localization and Institutional Change in Asian Regionalism', International Organization, 58/2: 239-75.

2. Acuto, M. (2010) 'Global Cities: Gorillas in Our Midst', Alternatives, 35: 425-48.

3. ---- (2013) 'City Leadership in Global Governance', Global Governance: A Review of Multilateralism and International Organizations, 19/3:481-98.

4. Amen M., Toly N.J., McCarney, P., Segbers. K. eds (2011) Cities and Global Governance: New Sites for International Relations. Aldershot: Ashgate. 
5. Alef-Act for Human Rights, “Two Years On: Syrian Refugees in Lebanon,” September 2013, ALEF: Beirut.

6. Bache, I., Flinders, M. eds (2004) Multi-level Governance, Oxford: Oxford University Press.

7. Bansard, J.S., Pattberg, P.H. and Widerberg, O. (2017) 'Cities to the rescue? Assessing the performance of transnational municipal networks in global climate governance', International Environmental Agreements: Politics, Law and Economics, 17/2: 229-46.

8. Bansak, K., Hainmueller, J. and Hangartner, D., 2016. How economic, humanitarian, and religious concerns shape European attitudes toward asylum seekers. Science, 354(6309), pp.217-222.

9. Barber, B. R. (2013) If Mayors Ruled the World: Dysfunctional Nations, Rising Cities, New Haven: Yale University Press.

10. Bennett, A. and George, A.L., 1997. Process tracing in case study research. Washington, DC: MacArthur Program on Case Studies.

11. Bennett, J., 1987. Event causation: The counterfactual analysis. Philosophical perspectives, 1, pp.367-386.

12. Betts, A., Ali, A. and Memişoğlu, F., 2017. Local politics and the Syrian refugee crisis: Exploring responses in Turkey, Lebanon, and Jordan. University of Oxford. Refugee Studies Centre.

13. Bluhm, M. (2007) 'How EDZ brought 24/7 Electricity to Zahle', Daily Star 23 March.

http://www.dailystar.com.lb/Business/Lebanon/2007/Mar-23/46873-new-zahle-plant-means-cheaper-wastetreatment-costs.ashx Accessed 4 May 2018.

14. Brenner, N. (1998) 'Global Cities, Glocal States: Global City Formation and State Territorial Restructuring in Contemporary Europe', Review of International Political Economy, 5/1: 1-37.

15. Callet-Ravat, L., Madore, M. (2016) The Role of Municipalities of Turkey and Lebanon in the Syrian Migratory Influx Management', UCLG-MEWA Publications.

16. Chatty, D., 2017. The Syrian humanitarian disaster: understanding perceptions and aspirations in Jordan, Lebanon and Turkey. Global Policy, 8, pp.25-32.

17. Çınar,A., Arıkan, B. (2002) 'The Nationalist Action Party: Representing the State, the Nation or the Nationalists', in Barry Rubin and Metin Heper (eds.) Political Parties in Turkey, London: Frank Cass, p. $25-$ 40 .

18. Cloward, K. (2015) 'Elites, Exit Options, and Social Barriers to Norm Change: The Complex Case of Female Genital Mutiliation', International Organization, 68/3: 495-526.

19. Çorabatır, M. (2016) The Evolving Response to Refugee Protection in Turkey: Assessing the Practical and Political Needs, Washington, DC: Migration Policy Institute.

20. Crawley, H., Özerim, G. (2016) 'Selling up, settling down: how a Turkish neighbourhood adapted to Syrian refugees', The Conversation, June 14.

21. Curtis, S. ed. (2014) The Power of Cities in International Relations, London: Routledge.

22. ---- (2016) Global Cities and Global Order, Oxford: Oxford University Press.

23. Demirkaya, Y. ed. (2016) New Public Management in Turkey: Local Government Reform, New York: Routledge.

24. DGMM (2018) Migration Statistics, Directorate General of Migration Management. Available at: http://www.goc.gov.tr/icerik/migration-statistics 9151024 (accessed 01 May 2018). 
25. Diab, A (2012) Armenians in Lebanon. Al-Akhbar. 22 April. Available at https://english.alakhbar.com/node/6454

26. Dinas, E., Matakos, K., Xefteris, D. and Hangartner, D., 2019. Waking up the golden dawn: does exposure to the refugee crisis increase support for extreme-right parties?. Political Analysis, 27(2), pp.244-254.

27. Dionigi, F. (2017) 'Statehood and Refugees: Patterns of Integration and Segregation of Refugee Populations in Lebanon from a Comparative Perspective', Middle East Law and Governance, 9/2: 113-146.

28. Erdoğan, M. (2017) Urban Refugees from Detachment to Harmonization, Syrian Refugees and Process Management of Municipalities: the case of Istanbul, Istanbul: Marmara Municipalities Union Publications.

29. Erdoğan, M., Kaya, A. eds. (2015) Türkiye'nin Göç Tarihi 14. Yüzyıldan 21. Yüzyıla Türkiye'ye Göçler, Istanbul: Bilgi University Press.

30. Fargues, P., Fandrich, C. (2012) 'The European Response to the Syrian Refugee Crisis, What Next?', Migration Policy Centre Research Report 14, Fiesole: European University Institute.

31. Finnemore, M., Sikkink, K. (1998) 'International norm dynamics and political change', International Organization, 52/4: 887-917.

32. Gotev, G. (2018) ‘Mayor of Gaziantep: EU owes Turkey more money’, EURACTIV, 28 January. Available at: https://www.euractiv.com/section/justice-home-affairs/news/mayor-of-gaziantep-eu-owes-turkey-moremoney/ (accessed 1 May 2018).

33. Gourevitch, P. (1978) 'The Second Image Reversed: The International Sources of Domestic Politics', International Organization, 32/4: 881-912.

34. Greenhill, K. M. (2010) Weapons of Mass Migration: Forced Displacement, Coercion and Foreign Policy, Ithaca: Cornell University Press.

35. Gül, P., Batman, S. (2016) 'Dünya ve Türkiye Örneklerinde Metropoliten Alan Yönetim Modelleri ve 6360 Sayılı Yasa', Yerel Politikalar, 3: 7-47.

36. Güneş-Ayata, A., Tütüncü, F. (2010) 'Party Politics of the AKP (2002-2007) and the Predicaments of Women at the Intersection of the Westernist, Islamist, and Feminist Discourses in Turkey', in Zahia Smail Salhi (ed.) Gender and Diversity in the Middle East and North Africa, Oxon: Abingdon, p. 71-92.

37. Haddad, E. (2008) The Refugee in International Society Between Sovereigns, Cambridge: Cambridge University Press.

38. Hainmueller, J. and Hopkins, D.J., 2014. Public attitudes toward immigration. Annual Review of Political Science, 17, pp.225-249.

39. Hamlin, R. (2014) 'Illegal refugees: competing policy ideas and the rise of deterrence in American Asylum Politics', Refugee Survey Quarterly, 31/2: 33-53.

40. Hangartner, D., Dinas, E., Marbach, M., Matakos, K. and Xefteris, D., 2019. Does exposure to the refugee crisis make natives more hostile?. American Political Science Review, 113(2), pp.442-455.

41. Harb, M, Atallah, S. (2015) 'Lebanon: A Fragmented and Incomplete Decentralization', in Mona Harb and Sami Atallah (eds) Local Governments and Public Goods: Assessing Decentralization in the Arab World, Beirut: The Lebanese Centre for Policy Studies.

42. Heper, M., Keyman, F. (2006) 'Double-faced state: political patronage and the consolidation of democracy in Turkey', Middle Eastern Studies, 34/4: 259-77. 
43. Hooghe, L., Marks, G. (2001) ‘Types of Multi-Level Governance’, European Integration Online Papers, 5/11: 1-24.

44. Hürriyet Daily News (2017) 'Municipality removes Arabic signs to "remove visual pollution” in Turkey’s south', May 22.

45. Içduygu, A. (2015) 'Syrian Refugees in Turkey, the Long Road Ahead', Migration Policy Institute, Washington, DC: Migration Policy Institute.

46. İçduygu, A., Diker, E. (2017) 'Labour Market Integration of Syrian Refugees in Turkey: From Refugees to Settlers', The Journal of Migration Studies, 3/1: 12-35.

47. Ilgıt, A., Memişoğlu, F. (2017) 'Contesting Refugees in Turkey: Political Parties \& the Syrian Refugees', in D. Utku, O. Unutulmaz and I. Sirkeci (eds) Syrian Communities in Turkey: Today and Tomorrow, Transnational Press London.

48. Ineli-Ciğer, M. (2014) 'Implications of the New Law on Foreigners and International Protection and Regulation No. 29153 on Temporary Protection for Syrians Seeking Protection in Turkey', Oxford Monitor of Forced Migration, 4/2: 28-36.

49. Janmyr, M. 2017. 'No Country of Asylum: 'Legitimizing' Lebanon's Rejection of the 1951 Refugee Convention'. International Journal of Refugee Law 29 (3).

50. Joppien, C. (2017) Municipal Politics in Turkey, Local Government and Party Organization, London: Routledge.

51. Kallius, A., Monterescu, D. and Rajaram, P. K. (2016) 'Immobilizing Mobility: Border Ethnography, Illiberal Democracy, and the Politics of the "Refugee Crisis" in Hungary', American Ethnologist, 43: 25-37. 52. Kangas, A. (2017) 'Global Cities, International Relations and the Fabrication of the World', Global Society, 31/4: 531-60.

53. Katzenstein, P.J. (1976) 'International Relations and Domestic Structures: Foreign Economic Policies of Advanced Industrial States', International Organization, 30/1: 1-45.

54. Kaya, A (2016) 'Syrian Refugees and Cultural Intimacy in Istanbul: I feel safe here', EUI Working Paper Series RSCAS 2016/59, Fiesole: European University Institute.

55. Kubicek, P. (2005) 'Turkish Accession to the European Union: Challenges and Opportunities', World Affairs, 168(2): 67-78.

56. Landau, B. L., Amit, R. (2014) 'Wither Policy? Southern African Perspectives on Understanding Law, 'Refugee' Policy and Protection', Journal of Refugee Studies, 27/4: 534-55.

57. Lebow, R.N., 2000. What's so different about a counterfactual?. World politics, 52(4), pp.550-585.

58. Lischer, S. (2005) Dangerous Sanctuaries: Refugee Camps, Civil War, and the Dilemmas of Humanitarian Aid, Ithaca, NY: Cornell University Press.

59. Ljungkvist, K. (2015) Global City 2.0: From Strategic Site to Global Actor, New York, NY: Routledge. 60. Loescher, G. (2001) The UNHCR and World Politics: A Perilous Path. New York: Oxford University. 61. McGranahan, C. (2016) 'Refusal and the Gift of Citizenship', Cultural Anthropology, 31: 334-341. 62. Miller, D. (2016) Strangers in Our Midst: The Political Philosophy of Immigration, Harvard: Harvard University Press.

63. Milner, J. (2009) Refugees, the State, and the Politics of Asylum in Africa, London: Palgrave MacMillan. 
64. Milliyet (2016) ‘Fatma Şahin’den Suriyelilere Vatandaşlık Açıklaması [Fatma Şahin’s Statement on Citizenship for Syrians], 16 July.

65. ---- (2017) '50,000 Konutluk Kuzey Şehir Yükseliyor [The North City with 50,000 houses is on the rise], 11 December.

66. ---- (2017a) 'Başkan Sözlü: Bizim için Kerkük Türklük’tür, Şah Damarımızdır’ [Mayor Sözlü: Kirkuk is Turkness for us] , 22 September.

67. Mourad. L (2017) “'Standoffish" Policy-making: Inaction and Change in the Lebanese Response to the Syrian Displacement Crisis', Middle East Law and Governance, 9(3): 249-266.

68. Moravcsik, A. (1995) 'Liberal Intergovernmentalism and Integration: A Rejoinder', Journal of Common Market Studies, 33: 611-628.

69. Mylonas, H. (2013) The Politics of Nation-Building: Making Co-Nationals, Refugees, and Minorities. New York, NY: Cambridge University Press.

70. Orchard, P. (2014) A Right to Flee, Refugees, States, and the Construction of International Cooperation, Cambridge: Cambridge University Press.

71. ---- (2015) 'Refugees and internally displaced persons', in R. Mac Ginty R., J. H. Peterson (eds), The Routledge Companion to Humanitarian Action, London: Routledge, pp. 298 - 309.

72. Ostrand, N. (2015) 'The Syrian Refugee Crisis: A Comparison of Response by Germany, Sweden, the United Kingdom, and the United States', Journal on Migration and Human Security, 3/3: 255-279.

73. Öztı̆̆, L. I. (2016) 'The Syrian Conflict and Turkeys Humanitarian Response', Turkish Policy Quarterly, Fall: 139-47.

74. Robertson, R. (1995) 'Glocalization: Time-Space and Homogeneity- Heterogeneity’, in M. Featherstone, S. Lash and R. Robertson (eds.) Global Modernities, London: Sage, pp. 25-44.

75. Roudometof, V. (2005) 'Transnationalism, Cosmopolitanism and Glocalization', Current Sociology, 53/1: 113-135.

76. Salehyan, I (2009) Rebels Without Borders: Transnational Insurgencies in World Politics, Ithaca, NY: Cornell University Press.

77. Sassen, S. (2002) 'The Repositioning of Citizenship: Emergent Subjects and Spaces for Politics', Berkeley Journal of Sociology, 46, 4-26.

78. Schmidt, A. (2014) 'Status Determination and Recognition, in Betts, A and Orchard, P (eds), Implementation in World Politics: How Norms Change Practice (Oxford: Oxford University Press).

79. Scott J. C. (1998). Seeing like a state: How certain schemes to improve the human condition have failed. Yale University Press

80. Slater, D., \& Kim, D. (2015). 'Standoffish States: Nonliterate Leviathans in Southeast Asia'. TRaNS: TransRegional and-National Studies of Southeast Asia, 3/1: 25-44.

81. Suhrke, A. (1998) 'Burden-sharing during Refugee Emergencies: The Logic of Collective versus National Action', Journal of Refugee Studies, 11/4: 396-415.

82. Tan, D. (2016) ‘Contextualizing Refugee NGOs in Izmir’, in D. Eroğlu, J.H. Cohen, I. Sirkeci (eds.) Turkish Migration Selected Papers, London: TPL.

83. Tetlock, P.E. and Belkin, A. eds., 1996. Counterfactual thought experiments in world politics: Logical, methodological, and psychological perspectives. Princeton University Press. 
84. Thielemann, E. R. (2003) 'Between Interests and Norms: Explaining Burden-Sharing in the European Union', Journal of Refugee Studies, 16/3: 253-73.

85. Tsouparas, G. (2017) 'The Politics of Exit: Emigration and Subject-Making Processes in Modern Egypt', Journal of Middle East and North African Migration Studies, 4/1: 29-49.

86. Turner, L. (2015) 'Explaining the (Non-)Encampment of Syrian Refugees: Security, Class and the Labour Market in Lebanon and Jordan', Mediterranean Politics, 20/3: 1-19.

87. UNDP (2017) 'Waste Management for Host Communities Project Opening, UNDP Turkey, March 20.

88. UNHCR (2017) 'Global Trends: Forced Displacement in 2016', The UN Refugee Agency.

89. ----- (2018) 'Syrian Regional Refugee Response', The UN Refugee Agency Operational Portal.

90. Woods, A., Kayal1, N. (2016) 'Engaging Syrian Communities: The Role of Local Government in Istanbul', Istanbul Policy Centre, Sabanc1 University.

91. Yıldız,A., Uzgören, E. (2016) 'Limits to temporary protection: non-camp Syrian refugees in İzmir, Turkey’, Southeast European and Black Sea Studies, 16/2: 195-211.

\section{TABLE AND FIGURES LEGENDS}

Table 1.

Figure 1. 